\title{
Late Pleistocene to Holocene diversification and historical zoogeography of the Arabian killifish (Aphanius dispar) inferred from otolith morphology
}

\author{
AZAD TEIMORI ${ }^{1,2}$, LAITH ABD JALIL JAWAD ${ }^{3}$, LUBNA HAMOUD AL-KHARUSI ${ }^{3}$, \\ JUMA MOHAMED AL-MAMRY ${ }^{3}$ and BETTINA REICHENBACHER ${ }^{1}$ \\ ${ }^{1}$ Department of Earth- and Environmental Sciences, Ludwig-Maximilians-Universität München, Richard-Wagner-Strasse \\ 10, 80333 Munich, Germany. E-mail: a.teimori@lrz.uni-muenchen.de, b.reichenbacher@lrz.uni-muenchen.de \\ ${ }^{2}$ Department of Biology, Faculty of Sciences, Shahid-Bahonar University of Kerman, 22 Bahman Blvd. Kerman, \\ 76169-14111 Iran. \\ ${ }^{3}$ Ministry of Fisheries Wealth, P. O. Box 427, code 100 Muscat, Sultanate of Oman.
}

\begin{abstract}
SUMMARY: Aphanius dispar (Rüppell, 1829) is a common marine-euryhaline teleost fish in the Near East that has undergone considerable intraspecific differentiation. Otolith morphology is used to analyse the diversity within A. dispar in the Gulf of Oman (Sea of Oman) and the Persian Gulf. A total of 134 individuals from lagoons and inland habitats of Oman, the United Arab Emirates and southern Iran are analysed. The results revealed that otolith traits that are under genetic control are strikingly different from those that are under the influence of environmental factors. A clear spatial structure of the populations is detectable, suggesting that the environmental flexibility of $A$. dispar, vicariance events during the last glacial maximum (21000-18000 BP), dispersal in the course of the Early Holocene sea-level rise, and Holocene to presentday interruption of gene flow at the Strait of Hormuz have shaped the intraspecific differentiation of $A$. dispar. These factors may also be responsible for diversification within other marine-euryhaline fishes in the Near East and Mediterranean Sea, and thus the findings can contribute to successful conservation management.
\end{abstract}

Keywords: Cyprinodontidae, otolith, Arabian Sea, Persian Gulf, phylogeography, Pleistocene, biodiversity.

RESUMEN: DiversificaCión e historia zoOgeográfica del Pleistoceno SUPerior al Holoceno en AphaniUs dispaR DETERMinada a PARTIR DE la morfología del otolito. - Aphanius dispar (Rüppell, 1829) es un teleósteo eurihalino común en aguas de Oriente Medio que presenta una considerable variación intraespecífica. El presente trabajo estudia la diversidad de A. dispar entre especímenes del Mar de Omán y del Golfo Pérsico a partir de la morfología de los otolitos. Se han analizado un total de 134 individuos procedentes de lagunas salobres y aguas interiores procedentes de Omán, Unión de Emiratos Árabes e Irán. Los caracteres morfológicos de los otolitos regulados genéticamente son distintos de los influenciados por factores ambientales. Se ha detectado una estructura espacial de las poblaciones, sugiriendo una plasticidad ambiental de A. dispar, un proceso de vicariancia durante la última glaciación (21000-18000 AP), una dispersión durante el aumento del nivel del mar a inicios del Holoceno y una interrupción del flujo genético en el estrecho de Ormuz desde el Holoceno a la actualidad. Los factores descritos podrían ser los causantes de la diversificación en otros peces eurihalinos de Oriente Medio y del Mar Mediterráneo y determinarlos podría contribuir a su conservación.

Palabras clave: Cyprinodontidae, otolito, mar Arábigo, golfo Pérsico, filogeografía, Pleistoceno, biodiversidad.

\section{INTRODUCTION}

The species of the Old-World killifish Aphanius (Teleostei: Cyprinodontidae) typically thrive in coastal and freshwater environments along the Mediterranean Sea,
Red Sea, Persian Gulf and Arabian Sea that are not suitable as habitats for other fishes, and thus often lack direct competitors and major predators (Clavero et al. 2007).

Aphanius species tolerate a wide range of temperature and salinity regimes, and their small size permits 


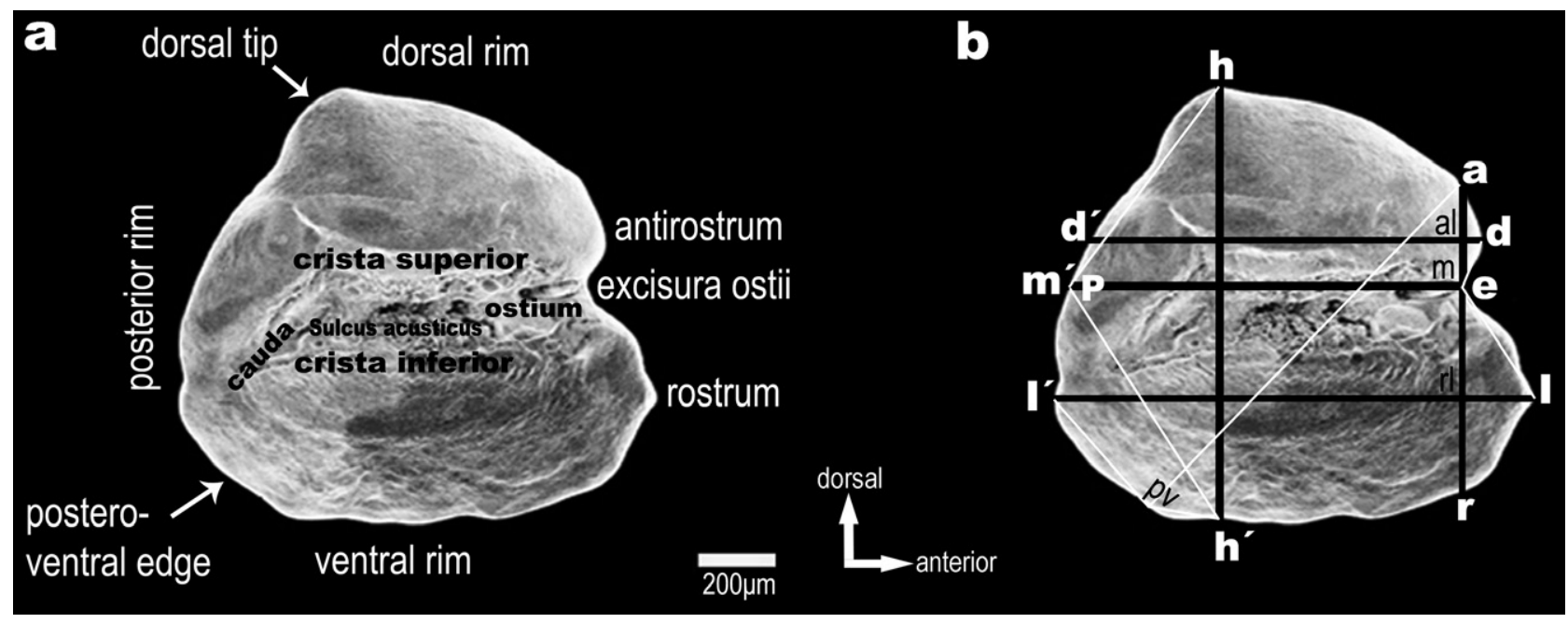

FIG. 1. - Otolith morphology (a) and morphometry (b) of Aphanius dispar from a coastal lagoon near Sib, Oman (site 2); otolith is shown in medial view. Terminology of otolith characters follows Nolf (1985); linear measurements and angles after Reichenbacher et al. (2007). 1-1 length, h-h' height, $\mathrm{m}-\mathrm{a}$ antirostrum height, $\mathrm{m}-\mathrm{r}$ rostrum height, rl-l rostrum length, al-d antirostrum length, $\mathrm{m}-\mathrm{m}^{\prime}$ medial length, d-d' dorsal length, e excisura angle, p posterior angle, pv posteroventral angle.

viable populations to persist in restricted habitats (e.g. Wildekamp 1993). These abilities also allow the translocation of individuals via drainage shifting and stream capture and promote survival of isolated and relict populations (Echelle and Echelle 1992). This group of fishes therefore represent particularly useful organisms for the study of microevolutionary processes in vertebrates (e.g. Tigano et al. 2006; Rocco et al. 2007).

The diversity within the Mediterranean and Anatolian species of Aphanius has been studied intensively for successful conservation management, reconstruction of phylogeography, and identification of the factors that affect genetic differentiation (e.g. Maltagliati 1999, Tigano et al. 2006, Triantafyllidis et al. 2007). Recent methods used include analyses of molecular, meristic, morphometric and osteological characters (e.g. Doadrio et al. 2002, Hrbek and Meyer 2003, Maltagliati et al. 2003), as well as the study of coloration (Wildekamp 1993) and otoliths (Reichenbacher and Sienknecht 2001, Schulz-Mirbach et al. 2006, Reichenbacher et al. 2007).

However, the Arabian killifish (Aphanius dispar), which is quite common in the Near East, has received little scientific attention to date, although molecular data suggest that it does not represent a monophylum (Hrbek and Meyer 2003). The principal habitats of $A$. dispar are coastal lagoons, but also inland waters such as endorheic drainage systems and hot springs (Krupp 1983, Wildekamp 1993, Abdoli 2000). Pronounced intraspecific differences are known to exist in morphological characters of the individuals and otolith traits (Wildekamp 1993, Reichenbacher et al. 2009a, Teimori et al. 2012a). These differences suggest that some of the landlocked populations have been isolated since the last humid phase of the Holocene, approximately 5500 years ago (Preusser 2009), and perhaps represent species in statu nascendi.

\section{Otoliths}

Otoliths are aragonitic mineralizations located in the membraneous labyrinth of the inner ear of bony fishes. They play an important role in the senses of hearing and balance (see Popper et al. 2005 for a recent overview). The saccular otolith (or sagitta) is the largest otolith in most teleost fishes and the main type that has been studied (Fig. 1a). The morphology of this structure is usually genus- and species-specific and therefore used for taxonomic studies (e.g. Nolf 1985 , Smale et al. 1995, Volpedo and Echeverría 2000, Lombarte et al. 2006, Jawad et al. 2008, Tuset et al. 2008, 2012) and also to examine phylogeny (Knudsen et al. 2007, Nolf and Tyler 2006). In addition, variations in otolith size and contour are used in the discrimination of individual populations or stocks (e.g. Campana and Casselman 1993, Torres et al. 2000, Stransky et al. 2008), and also to detect genetic and environmental influences (Lombarte and Castellon 1991, Lombarte and Lleonart 1993, Lombarte et al. 2010).

In the case of Aphanius, particular otolith characters related to the length-height-index, rostrum and antirostrum remain stable within a given species also in the case of ecologically different habitats (Reichenbacher et al. 2007, Teimori et al. 2012a). They can be used to discriminate confidently not only the various coastal Mediterranean Aphanius species, but also closely related inland species such as those from Anatolia (Schulz-Mirbach et al. 2006) and Iran (Teimori et al. 2012b). The consistency of these otolith characters indicates that their formation is under genetic control and is scarcely influenced by environmental factors. Therefore, they can provide valuable information with regard to the diversification and phylogeography of Aphanius, and probably also those of other teleost fishes that possess otoliths 


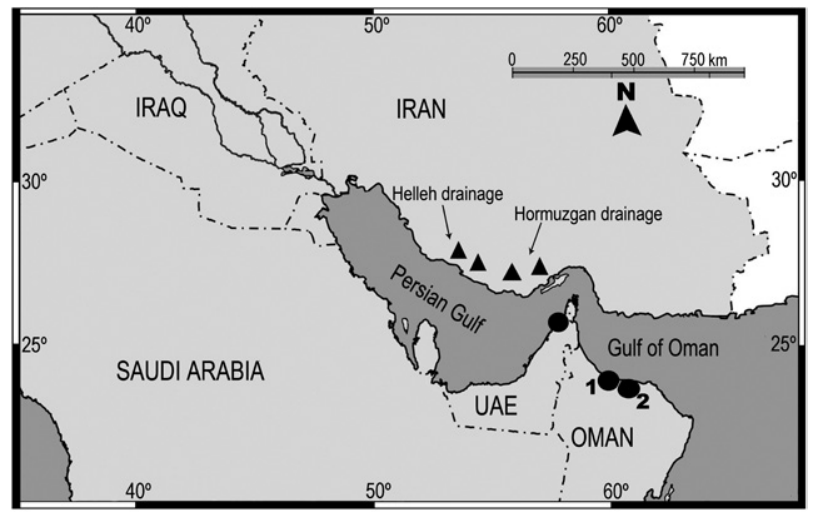

FIG. 2. - Map of sampling locations. Circles indicate coastal sites, triangles landlocked sites. 1 site 1 near Sib, Oman; 2 site 2 near Sib, Oman.

with a clear rostrum and antirostrum (see also Vignon and Morat 2010).

The objective of this study is to evaluate the divergence of coastal and landlocked A. dispar populations in the Gulf of Oman (Sea of Oman) and Persian Gulf based on qualitative and quantitative otolith data. Those otolith traits that can be assumed to be under genetic controls were used to analyse the phylogeography of $A$. dispar in the study area. The outcomes significantly enhance our understanding of the intraspecific diversity in A. dispar, and are probably also valid for other marine-euryhaline species in the Near East and the Mediterranean Sea.

\section{MATERIALS AND METHODS}

\section{Samples collection}

A total of 43 specimens of Aphanius dispar were collected from two coastal habitats near Sib city, Oman (site 1, 12 males, 14 females, 2340'19"N, $58^{\circ} 12^{\prime} 21^{\prime \prime} \mathrm{E}$; site 2, 7 males, 9 females, $23^{\circ} 40^{\prime} 28^{\prime \prime} \mathrm{N}$, $58^{\circ} 11^{\prime} 33^{\prime \prime} \mathrm{E}$ ) (Fig. 2). All specimens were adults with a standard length greater than $20 \mathrm{~mm}$ (total length 24.60$39.20 \mathrm{~mm}$ ). Fishes were preserved in $99.9 \%$ ethanol until dissection.

\section{Samples for comparison}

A total of 32 specimens ( 8 males, 24 females, total length 25.0-41.4 mm) were available from a coastal

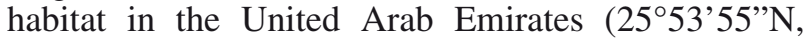
56 03' 23”'E) (Fig. 2; see Reichenbacher et al. 2009a). In addition, a total of 60 specimens from southern Iran were studied, i.e. 10 males and 10 females (total length 24.40-39.35 $\mathrm{mm}$ ) from hot springs within the Helleh Basin $\left(29^{\circ} 24^{\prime} 08^{\prime \prime} \mathrm{N}, 51^{\circ} 16^{\prime} 35^{\prime \prime} \mathrm{E} ; 28^{\circ} 47^{\prime} 56^{\prime \prime} \mathrm{N}\right.$, $51^{\circ} 16^{\prime} 51^{\prime \prime} \mathrm{E}$ ), and 23 males and 17 females (total length $24.40-42.35 \mathrm{~mm}$ ) from the Mehran and Shur river drainages within the Hormuzgan Basin $\left(27^{\circ} 08^{\prime} 40^{\prime \prime} \mathrm{N}\right.$,

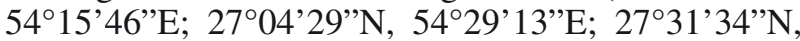
$56^{\circ} 28^{\prime} 08^{\prime \prime}$ ) (Fig. 2, see Teimori et al. 2012a). All specimens were adults with a standard length greater than $20 \mathrm{~mm}$. Fishes were kept in $99.9 \%$ ethanol until dissection.

According to the habitat descriptions for A. dispar from the United Arab Emirates and southern Iran (Reichenbacher et al. 2009a, Teimori et al. 2012a) and own observations at the sites in Oman, the general environmental conditions of the sites are comparable, i.e. all are shallow pools, the water energy is low, temperature and $\mathrm{pH}$ are generally within the range of $25-28^{\circ} \mathrm{C}$ and $\mathrm{pH} 8.0-9.5$, and salinity is about $0.05-3 \%$. However, it is possible that food availability, predator pressure, spawning success or other factors that we could not evaluate during our observations are differing among the sites.

\section{Otolith preparation and analysis}

Skulls were opened ventrally and right and left otoliths were removed. Otoliths were cleaned from tissue remains in $1 \%$ potassium hydroxide $(\mathrm{KOH})$ solution for $6 \mathrm{~h}$ and then rinsed in distilled water for 12 h. Otolith morphology was studied with a stereomicroscope. In addition, morphological comparisons were conducted using SEM images (LEO 1430 VP) of five representative otoliths from each population. For morphometric analyses, only left otoliths were used. They were positioned on plasticine with the lateral face down, and digital images were captured using a Leica DFC 295 camera and the IMAGIC 1000 software. Following the methodology introduced in Reichenbacher et al. (2007), eight linear distances and three angles were measured for each of the otoliths (Fig. 1b). Linear measurements were standardized as a function of length and height of otolith, respectively, and, together with the angle values, used as otolith variables in the statistical analyses. Moreover, the groupwise registration approach (Zöllei et al. 2005, Balci et al. 2007) was used for a comprehensive illustration of the otolith contour of a given population. This method provides a representative image based on the so-called average image. The representative image is close to all images in the data set but is not necessarily one of them.

\section{Statistical analyses}

Otolith variables were analysed using SPSS 19.00 (SPSS Inc. 2011) and PAST (PAlaeontological STatistics, version 1.81 (Hammer et al. 2001). The $t$ test was applied to determine whether otolith variables within a given population exhibit sex dimorphism. One-way ANOVA with Duncan Post-hoc test $(P<0.05)$ was used to test the significance of individual otolith variables. For multivariate analysis of otolith variables, canonical discriminant analysis (CDA) was performed (covariance homogeneity for all groups, all variables analysed together); classification success was tested with jackknifed cross-validation. 


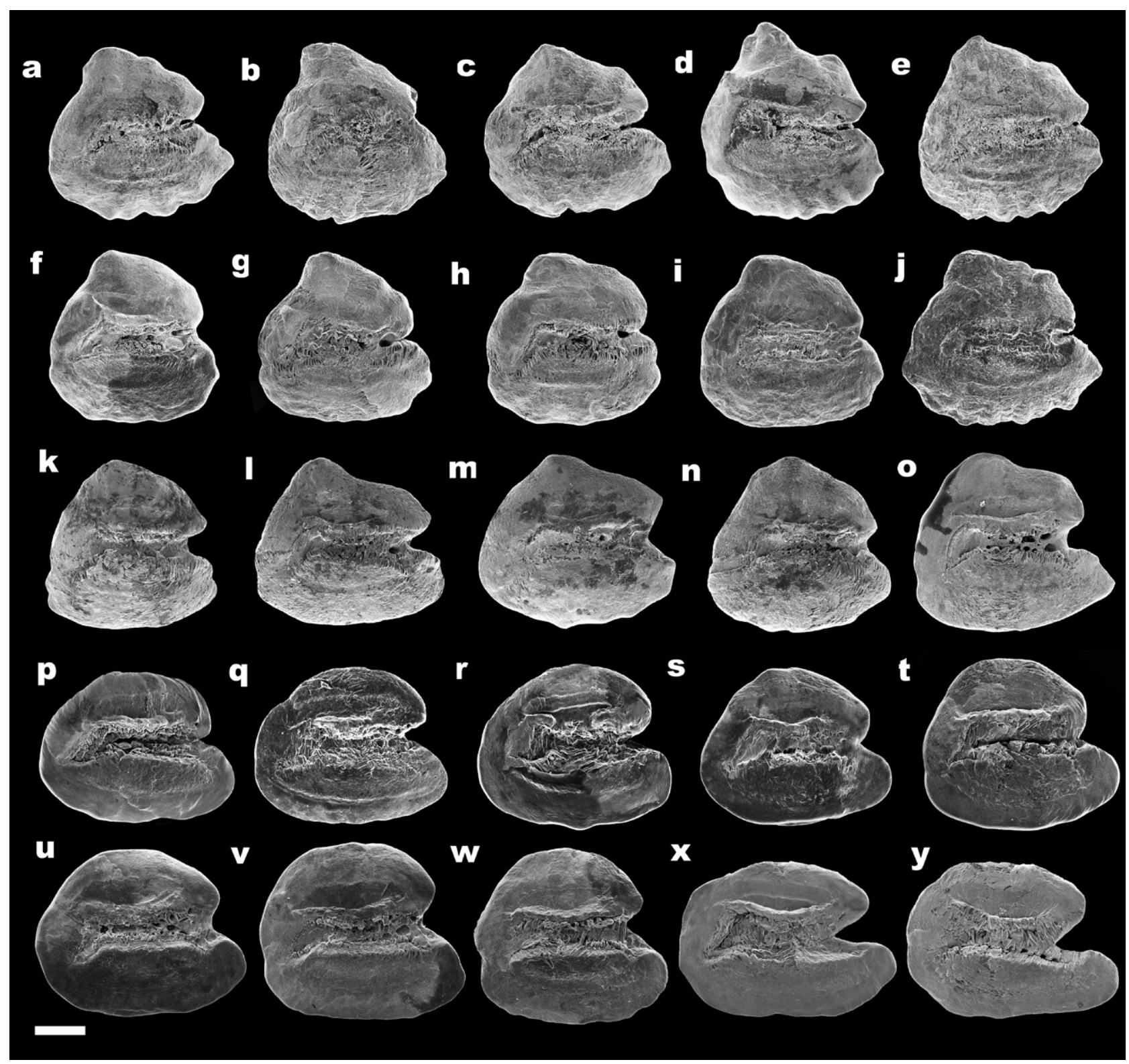

FIG. 3. - Otoliths of Aphanius dispar from the studied sites. a-e, site 1 near Sib, Oman; f-j, site 2 near Sib, Oman; k-o, Khor Hulaylah, United Arab Emirates; p-t, Hormuzgan Basin, Iran; u-y, Helleh Basin, Iran. Note presence and absence of a dorsal tip, distinctive shapes and different proportions of rostrum and antirostrum. All images are SEM micrographs, showing left otoliths in medial view. Scale bar $200 \mu \mathrm{m}$.

\section{RESULTS}

The otoliths of Aphanius dispar individuals from the two coastal sites in Oman (near Sib city) were quite similar in morphology (Fig. 3a-j); they are therefore considered here as belonging to one population. Their characters include a trapezoid-triangular shape, a prominent dorsal tip, slightly to strongly crenulated ventral and dorsal rims, a short rostrum and antirostrum, and a very narrow excisura. The otoliths of $A$. dispar from the Helleh and Hormuzgan Basins (southern Iran) (Fig. $3 p-y)$ differed clearly from the Oman population because of their narrow and rounded-triangular shape, absence of a dorsal tip, mostly non-crenulated rims, and the presence of a long rostrum and prominent antirostrum. The otoliths from the United Arab Emirates (Fig. 3k-o) are somewhat intermediate in morphology because they resemble the Oman specimens with regard to the trapezoid-triangular shape and dorsal tip, whereas their pronounced rostrum and antirostrum and widely opened excisura make them different from the Oman specimens but similar to the southern Iranian otoliths. This intermediate morphology is supported by the multivariate analysis, which plots the otoliths from the United Arab Emirates between the southern Iranian and Oman otoliths (Fig. 4).

In the statistical analyses, males and females were used together as only one otolith character (posterior 
TABLE 1. - Values of otolith variables (means and standard deviations) of the studied Aphanius dispar populations (one-way ANOVA with Duncan Post-hoc test, $P<0.05$ ); significantly different values of variables are highlighted in bold; $N$, number of individuals; $\mathrm{m}$, males; $\mathrm{f}$, females; UAE, United Arab Emirates.

\begin{tabular}{lcccc}
\hline Location & Oman & UAE & Hormuzgan/Iran & Helleh/Iran \\
\hline $\mathrm{N}(\mathrm{m} / \mathrm{f})$ & $42(19 / 23)$ & $32(8 / 24)$ & $40(23 / 17)$ & $20(15 / 13)$ \\
& & & & \\
Length-height-index $^{\mathrm{a}}$ & $\mathbf{1}( \pm 0.09)$ & $1.1( \pm 0.05)$ & $1.1( \pm 0.09)$ & $\mathbf{1 . 2}( \pm 0.1)$ \\
Relative antirostrum height $^{\mathrm{a}}$ & $\mathbf{2 2 . 4}( \pm 6.2)$ & $29.3( \pm 4.1)$ & $29.4( \pm 5.2)$ & $\mathbf{3 2 . 2}( \pm 6.2)$ \\
Relative rostrum height $^{\mathrm{a}}$ & $\mathbf{4 1 . 9}( \pm 5.6)$ & $44.1( \pm 3.2)$ & $44.8( \pm 5.1)$ & $\mathbf{4 9 . 9}( \pm 3.1)$ \\
Relative rostrum length $^{\mathrm{a}}$ & $14.2( \pm 4.3)$ & $17.1( \pm 3.4)$ & $15.5( \pm 4.4)$ & $\mathbf{2 2 . 5}( \pm 5.8)$ \\
Relative antirostrum length $^{\mathrm{b}}$ & $\mathbf{6 . 4}( \pm 3.2)$ & $10.7( \pm 2.7)$ & $8.3( \pm 3.1)$ & $\mathbf{1 1 . 4}( \pm 5.1)$ \\
Relative medial length $^{\mathrm{b}}$ & $\mathbf{8 6 . 3}( \pm 4.8)$ & $81.8( \pm 4.4)$ & $83.5( \pm 5.2)$ & $\mathbf{7 8 . 7}( \pm 5.3)$ \\
Excisura angle $^{\mathrm{b}}$ & $120.6( \pm 11.1)$ & $105.3( \pm 12.6)$ & $115.3( \pm 14.2)$ & $104.8( \pm 22.3)$ \\
Posterior angle $^{\mathrm{b}}$ & $\mathbf{1 3 8 . 8}( \pm 9.5)$ & $97.6( \pm 7.3)$ & $89.4( \pm 8.9)$ & $87.6( \pm 7.4)$ \\
Relative dorsal length $^{\text {Postero-ventral angle }}$ & $85.6( \pm 5.5)$ & $85.9( \pm 5.6)$ & $85.9( \pm 7.5)$ & $82.3( \pm 3.3)$ \\
\hline
\end{tabular}

${ }^{a}$ variables that are usually consistent within a species (regardless of the ecological situation) and thus under genetic constrains

${ }^{b}$ variables that are known to display variation due to different ecological conditions

angle) showed sexual dimorphism ( $t$ test, $P<0.05)$. Six otolith variables were significantly different for A. dispar from Oman and the Helleh Basin, respectively, whereas a single and no otolith variable was significant for the United Arab Emirates and Hormuzgan Basin populations, respectively (one-way ANOVA with Duncan post-hoc test, $P<0.05$; Table $1)$. The otolith variables that were significantly different for the Oman and Helleh Basin populations include the length-height index, relative antirostrum height, relative rostrum height, relative antirostrum length and relative medial length. In addition, the posterior angle separated the Oman population from the others, whereas the relative rostrum length was significant for A. dispar from the Helleh Basin (Table 1). The high value of the posterior angle in the Oman individuals was related to the position of the dorsal tip slightly behind or in the middle of the dorsal rim (Fig. 3a-j). Additionally, the populations studied were separated with high overall classification success $(88.6 \%)$ based on the multivariate analysis (CDA) of all otolith variables (Table 2, Fig. $4)$. The classification was even better for the Oman individuals $(92.5 \%)$.

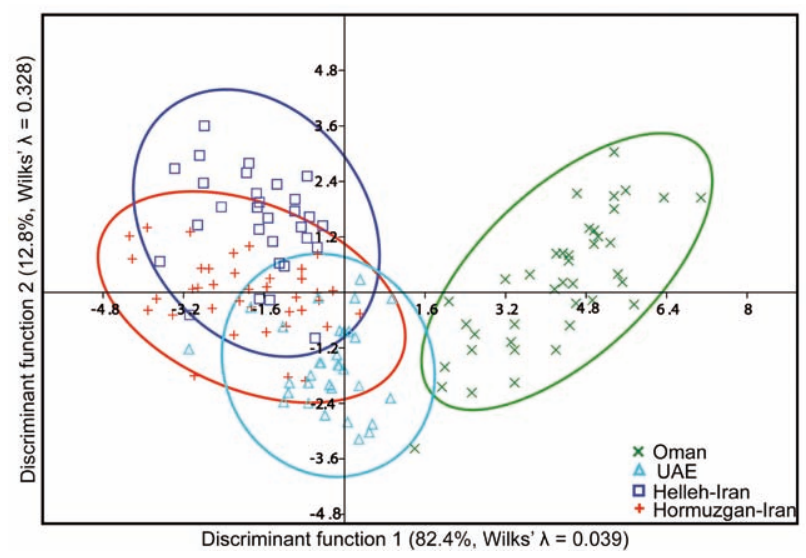

FIG. 4. - Discriminant function scores with $95 \%$ ellipses for all otolith variables of Aphanius dispar populations.
TABLE 2. - Classification matrix of the CDA (jack-knifed) based on all otolith variables of the studied Aphanius dispar populations.

\begin{tabular}{lccccc}
\hline \multirow{2}{*}{ Location } & \multicolumn{5}{c}{ Predicted classification } \\
& Oman & UAE & Hormuzgan & Helleh & N \\
\hline Oman & $\mathbf{9 2 . 5 ( 3 8 )}$ & $5.0(3)$ & $2.5(1)$ & 0 & 42 \\
UAE & 0 & $\mathbf{6 2 . 5}(\mathbf{2 0})$ & $25(8)$ & $12.5(4)$ & 32 \\
Hormuzgan/Iran & $2.5(1)$ & $15(6)$ & $\mathbf{8 0}(\mathbf{3 2})$ & $2.5(1)$ & 40 \\
Helleh/Iran & 0 & 0 & $20.2(4)$ & $\mathbf{7 7 . 8}(\mathbf{1 6})$ & 20 \\
\hline
\end{tabular}

The percentages in rows represent the classification into the populations given in columns (correct classifications are highlighted in bold); corresponding numbers of individuals are given in brackets. Overall classification success is $88.6 \%$ (Wilks' $\lambda=0.039$ for function 1 and 0.328 for function 2). $N$, number of individuals; UAE, United Arab Emirates.

\section{DISCUSSION}

\section{Environmentally vs. genetically influenced otolith characters}

In fish species, some otolith characters may display intraspecific variation resulting from habitat-specific physical or ecological parameters such as water depth, water temperature, habitat productivity and diet availability (e.g. Lombarte and Lleonart 1993, Torres et al. 2000, Lombarte et al. 2010). In the case of Aphanius, these environmentally influenced otolith characters comprise the relative antirostrum length, relative medial length, excisura angle, and posterior angle (Reichenbacher et al. 2007, 2009b, Teimori et al. 2012a). Thus, their variation between A. dispar individuals from the studied localities (see Table 1) may indicate some environmental differences between the habitats, e.g. differences in food availability, predator pressure or spawning success.

However, in addition to the otolith variation caused by environmental factors, the individuals of $A$. dispar from Oman and the Helleh Basin are characterized by otolith variables that can be assessed as genetically controlled on the basis of previous studies on Aphanius (Reichenbacher et al. 2007, 2009a,b, Teimori et al. 2012a). These otolith variables include the length-height-index, relative antirostrum height and relative rostrum height 

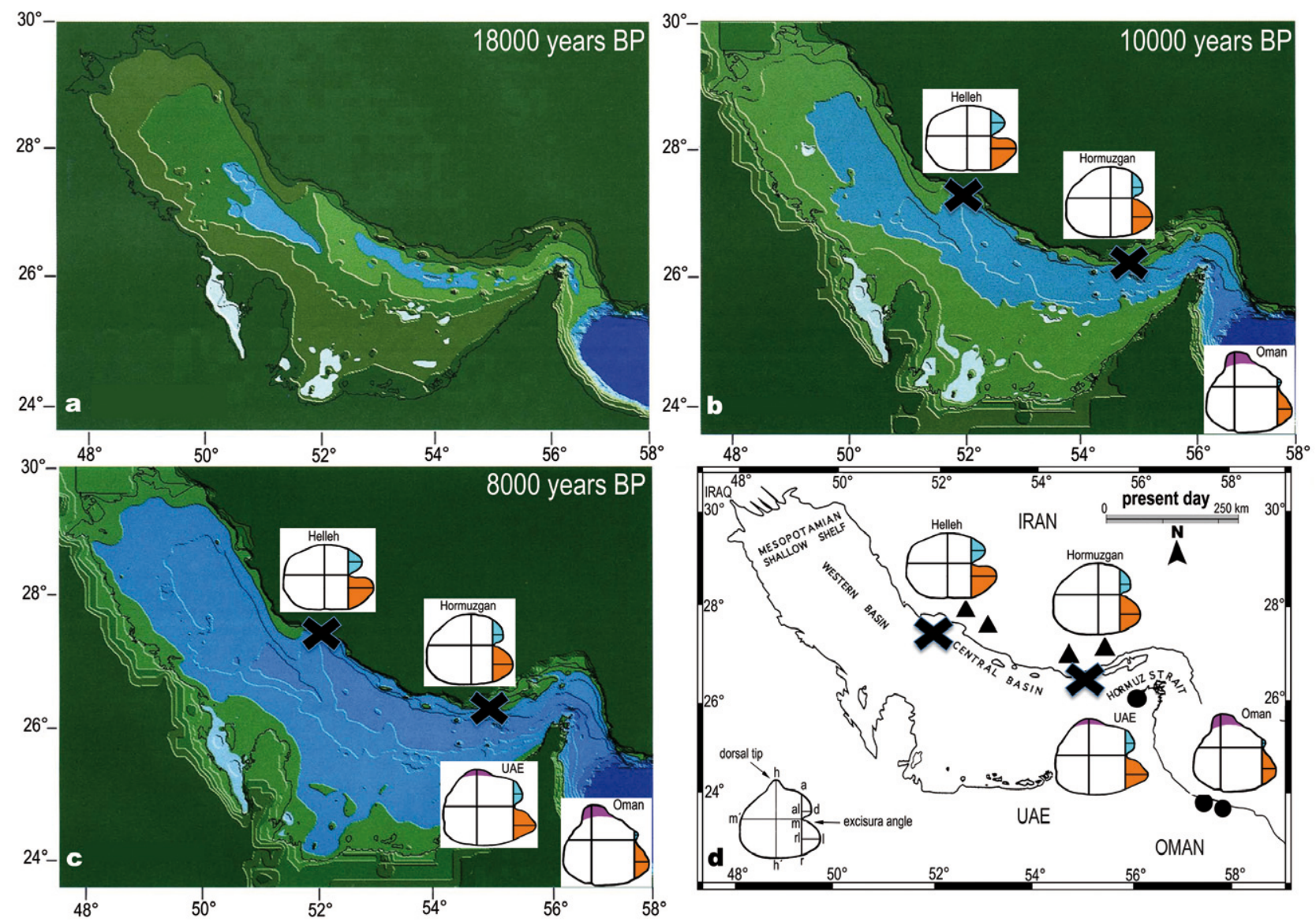

FIG. 5. - Historical zoogeography of Aphanius dispar as indicated by genetically constrained otolith characters. a, subaerially exposed Persian Gulf sea floor during the last glacial maximum of the Late Pleistocene; b-c, Early Holocene re-flooding of the Persian Gulf, black crosses indicating absence of gene flow between $A$. dispar inland populations and immigrants from the Gulf of Oman; d, present-day situation of the Persian Gulf, circles showing coastal sites, triangles landlocked sites, black crosses absence of gene flow between A. dispar inland populations and coastal A. dispar individuals. Otolith images are representative images of the groupwise registration method; linear distances in otolith images represent selected morphometric distances (see inset in d and Figure 1). Source of maps: Purser and Seibold (1973), Lambeck (1996), Teller et al. (2000).

(Table 1) and their variation indicates considerable genetic diversification within A. dispar. A further line of evidence to support this assumption comes from a study on the coral reef snapper Lutjanus kasmira (Vignon and Morat 2010), which found that intra-specific genetic divergence due to long-time separation affects otolith shape locally and re-shapes mainly the antirostrum and rostrum. This finding reinforces the significance of the antirostrum and rostrum variation for a tentative evaluation of intraspecific diversity in A. dispar, and probably also in many other teleost species that possess otoliths with an antirostrum and rostrum.

\section{Glacial-postglacial Persian Gulf history and historical zoogeography of Aphanius dispar}

Our data show a clear spatial distribution pattern of the otolith characters antirostrum and rostrum and additionally of the dorsal tip. A weakly developed antirostrum and rostrum co-occur with a long dorsal tip in the individuals from Oman; a prominent antirostrum and rostrum, but no dorsal tip are present in the individuals from the Helleh and Hormuzgan Basins; and a moderately developed antirostrum co-occurs with a comparatively short dorsal tip in the individuals from the United Arab Emirates and the Hormuzgan Basin (Figs 3, 5).

We now consider the factors that may have contributed to the development of this spatial pattern within A. dispar.

The average depth of the Persian Gulf today is about $35 \mathrm{~m}$, while the maximum depth, restricted to the central basin off the southern coast of Iran, is $100 \mathrm{~m}$ (Purser and Seibold 1973). The runoff into the Persian Gulf derives from the Tigris and Euphrates rivers at the northwestern margin, and from rivers draining the Zagros Mountains at the northern central margin (the present-day Helleh and Hormuzgan Basin, southern Iran); almost no runoff comes from the arid Arabian Peninsula (Teller et al. 2000).

During the last glacial maximum of the Late Pleistocene (21000-18000 BP), global sea-level was at 
$-120 \mathrm{~m}$ and the Persian Gulf sea floor was subaerially exposed (Sarnthein 1972, Lambeck 1996, Teller et al. 2000; Fig. 5a). During that time and until the Holocene sea-level rise in $11000 \mathrm{BP}$, the Tigris and Euphrates rivers, as well as the rivers from the Zagros Mountains, probably fed a large ancient stream that flowed across the exposed Persian Gulf sea floor to the Hormuz Strait (Lambeck 1996, Teller et al. 2000).

It is clear that all stenohaline-marine species must have disappeared from the sea in the Persian Gulf between 21000 and 11000 BP. However, A. dispar is a marine-euryhaline species, and today also occurs in rivers and hot springs (see Introduction). It can therefore be hypothesized that the A. dispar individuals, which existed in the Persian Gulf sea before the last glacial maximum, could adapt to the changing conditions and were able to thrive in the freshwater environments on the exposed sea floor and also in the rivers coming from Mesopotamia and southern Iran.

The Early Holocene re-flooding of the Persian Gulf around $11000 \mathrm{BP}$ advanced through the Hormuz Strait, but was initially restricted to the deepest part of the central basin off the southern Iranian coast (Lambeck 1996, Teller et al. 2000, Smith et al. 2011; Fig. 5b). In the course of this flooding new marine species from the Gulf of Oman and the Arabian Sea migrated into the sea of the Persian Gulf (see Hoolihan et al. 2004, Kennett and Kennett 2006) and, together with these species, also individuals of A. dispar. However, since the last glacial maximum (Late Pleistocene), i.e. for about 10000 years, these immigrants had been isolated from those A. dispar individuals that had survived the Late Pleistocene non-marine phase within the Persian Gulf. It is therefore likely that the immigrants did not interbreed with the "native" individuals inhabiting freshwater environments, because of either genetic divergence or environmental constraints. This assumption offers an explanation as to why the individuals in the Helleh Basin, which today live in endorheic systems and hot springs, show the highest divergence of their otolith characters in comparison with the marine individuals from Oman: the former are descendants of the "native" non-marine Late Pleistocene population, while the latter are descendants from the Early Holocene marine immigrants. Notably, the Helleh Basin individuals display not only high divergence of otolith traits, but also high divergence of the morphometric and meristic characters of the fish body (Teimori et al. 2012a). The A. dispar population in the rivers of the Hormuzgan Basin (which drain to the Persian Gulf) are somewhat transitional between the populations from the Helleh Basin and Oman due to their elongate to rounded shape and medium-sized antirostrum (Figs 3, 5). A possible explanation would be that they are "hybrids" of some ancient non-marine Late Pleistocene individuals and Early Holocene marine immigrants.

By $8000 \mathrm{BP}$, the southern and westernmost areas of the Persian Gulf had also become marine (Lambeck 1996, Teller et al. 2000; Fig. 5c). The fauna of the now drowned ancient waterway on the Persian Gulf sea floor (including the non-marine populations of $A$. dispar) probably retreated to the lower reaches of the present-day Tigris and Euphrates rivers in Mesopotamia, and the marine immigrants from the Gulf of Oman and Arabian Sea became widespread in the entire region of the Persian Gulf (Hoolihan et al. 2004, Kennett and Kennett 2006).

Following this scenario, the existence of genetic differences between present-day A. dispar individuals from coastal habitats inside and outside the Persian Gulf is unlikely, as the populations can be assumed to be in contact with one another. However, the results of this study indicate that genetic divergence exists between the coastal individuals from Oman (outside the Persian Gulf) and those from the United Arab Emirates (inside the Persian Gulf) (Fig. 5d). Hoolihan et al. (2004) presented similar results for marine sailfish populations (Istiophorus platypterus) based on mtDNA analyses. These authors suggested as the most plausible explanations not only the restricted physical size of the Hormuz Strait, but also the presence of ecological barriers to gene flow such as higher salinity level and more extreme water temperature shifts in the Persian Gulf than in the Gulf of Oman and Arabian Sea. This hypothesis is very appropriate for explaining also the genetic divergence between the coastal $A$. dispar individuals from Oman and the United Arab Emirates reported herein.

\section{CONCLUSIONS}

The intraspecific variation of $A$. dispar from the Gulf of Oman and the Persian Gulf, as inferred from otolith differences, can be linked to (i) vicariance events due to the sea-level drop of the last glacial maximum (Late Pleistocene; 21000-18000 BP), (ii) environmental flexibility of $A$. dispar, (iii) dispersal during the Early Holocene sea-level rise (11000-8000 BP), and (iv) Holocene to present-day ecological barriers to gene flow at the Hormuz Strait. The most distant A. dispar populations are those from the Gulf of Oman and the Helleh Basin in southern Iran; these populations have probably been isolated since the last glacial maximum, i.e. for about 20000 years. The Helleh populations may be closely related to the present-day A. dispar populations of the Tigris and Euphrates river systems in Iraq, with which they may have shared the freshwater habitats on the exposed Persian Gulf sea floor between the Late Pleistocene last glacial maximum and Early Holocene sea-level rise. Present-day divergence between coastal populations in and outside the Persian Gulf most likely results from ecological barriers to gene flow at the Hormuz Strait, as suggested in a previous study on a marine sailfish species. The same factors that have shaped the pattern of diversity within A. dispar have probably also formed within-species diversity of other marine-euryhaline fish species in the Persian Gulf, the Near East and the Mediterranean Sea. Study 
of their otolith differences should be a suitable tool for contributing to a successful conservation management of these species.

\section{ACKNOWLEDGEMENTS}

We thank the Iranian Ministry of Sciences, Research and Technology for financial support to the first author, the Ministry of Fisheries Wealth, Marine Science and Fisheries Centre, and the directorate of Agriculture and Fisheries Developmental Fund for giving us the opportunity to work on the fish samples within the qualitative and quantitative distribution of marine organisms in the Sultanate of Oman and for providing the necessary financial support. We thank R. Melzer for providing access to the SEM at the Bavarian State Collection of Zoology (ZSM, Munich) and M. Krings (Munich) for improving the English. The authors would like to thank two anonymous reviewers and the editor, Dolors Vaque, for their valuable comments and recommendations for improving the manuscript.

\section{REFERENCES}

Abdoli A. 2000. The Inland Water Fishes of Iran. Iranian Museum of Nature and Wildlife, Tehran, 378 pp. In Farsi.

Balci S.K., Golland P., Shenton M., Wells WM. 2007. Free-Form B-spline Deformation Model for Groupwise Registration. Med. Image Comput. Comput. Assist. Interv. 10: 23-30

Clavero M., Blanco-Garrido F., Prenda J 2007. Population and microhabitat effects of interspecific interactions on the endangered Andalusian toothcarp (Aphanius baeticus). Environ. Biol. Fish. 78: 173-182.

Campana S.E., Casselman J.M. 1993. Stock discrimination using otolith shape analysis. Can. J. Fish. Aquat. Sci. 50: 1062-1083.

Doadrio I., Carmona J.A., Fernández-Delgado C. 2002. Morphometric study of the Iberian Aphanius (Actinopterygii, Cyprinodontiformes), with description of a new species. Folia. Zool. 51: 67-79.

Echelle A.A., Echelle A.F. 1992. Mode and pattern of speciation in the evolution of inland pupfishes in the Cyprinodon variegatus complex (Teleostei: Cyprinodontidae): An ancestor-descendent hypothesis. In: Mayden R.L. (eds.), Systematics, Historical Ecology, and North American Freshwater Fishes. Stanford University Press, Stanford, California, pp. 691-709.

Hammer Ø., Harper D.A.T., Ryan PD. 2001. PAleontological STatistics Software Package For Education And Data Analysis. Palaeontol. Electron. 4: 1-9.

Hoolihan J.P., Premanandh J., D'Aloia-Palmieri M-A., Benzie J.A.H. 2004. Intraspecific phylogeographic isolation of Persian Gulf sailfish Istiophorus platypterus inferred from mitochondrial DNA. Mar. Biol. 145: 465-475.

Hrbek T., Meyer A. 2003. Closing of the Tethys Sea and the phylogeny of Eurasian killifishes (Cyprinodontiformes: Cyprinodontidae). J. Evol. Biol. 16: 17-36.

Jawad L.A., Al-Jufaili S.A., Al-Shuhaily S.S. 2008. Morphology of the otolith of the greater lizardfish Saurida tumbil (Pisces: Synodontidae). J. Nat. Hist. 42: 2321-2330.

Kennett D.J., Kennett J.P. 2006. Early State Formation in Southern Mesopotamia: Sea Levels, Shorelines, and Climate Change. J. Island. Coastal. Archaeol. 1: 67-99.

Knudsen E.W., Møller P.R., Gravlund P. 2007. Phylogeny of the snailfishes (Teleostei: Liparidae) based on molecular and morphological data. Mol. Phyl. Evol. 44: 649-666.

Krupp F. 1983. Freshwater fishes of Saudi Arabia and adjacent regions of the Arabian Peninsula. Fauna Saudi Arabia. 5: 568-636

Lambeck K. 1996. Shoreline reconstructions for the Persian Gulf since the last glacial maximum. Earth Planet Sci. Lett. 142: 43-57.
Lombarte A., Castellón A. 1991. Interspecific and intraspecific variability in the genus Merluccius as determined by image analysis. Can. J. Zool. 69: 2442-2449.

Lombarte A., Lleonart J. 1993. Otolith size changes related with body growth, habitat depth and temperature. Environ. Biol. Fish. 37: 297-306.

Lombarte A., Palmer M., Matallanas J., Gómez-Zurita J., MoralesNin B. 2010. Ecomorphological trends and phylogenetic inertia of otolith sagittae in ototheniidae. Environ. Biol. Fish. 89: 607-618.

Lombarte A., Chic O., Parisi-Baradad V., Olivella R., Piera J., Garcia-Ladona E. 2006. A web-based environment for shape analysis of fish otoliths. The AFORO database*. Sci. Mar. 70: 147-152.

Maltagliati F. 1999. Genetic divergence in natural populations of the Mediterranean brackish-water killifish Aphanius fasciatus. Mar. Ecol. Prog. Ser. 179: 155-162.

Maltagliati F., Domenici P., Fosch C.F., Cossu P., Casu M., Castelli A. 2003. Small-scale morphological and genetic differentiation in the Mediterranean killifish Aphanius fasciatus (Cyprinodontidae) from a coastal brackish-water pond and an adjacent pool in northern Sardinia. Oceanol Acta. 26: 111-119.

Nolf D. 1985. Otolithi piscium. Handbook of paleoichthyology. Gustav Fischer, Stuttgart, New York

Nolf D., Tyler J.C. 2006. Otolith evidence concerning interrelationships of caproid, zeiform and tetradontiform fishes. Bull. Inst. Roy. Sci. Nat. Belg. Sci. Terre 76: 147-189.

Popper AN., Ramcharitar JU., Campana SE. 2005. Why otoliths? Insights from inner ear physiology and fisheries biology. Mar. Freshw. Res. 56: 497-504.

Preusser F. 2009. Chronology of the impact of Quaternary climate change on continental environments in the Arabian Peninsula. Compt. Rendues. Geosci. 341: 621-632.

Purser B.H., Seibold E. 1973. The principal environmental factors influencing Holocene sedimentation and diagenesis in the Persian Gulf. In: Purser B.H. (eds.), The Persian Gulf: Holocene Carbonate Sedimentation and Diagenesis in a Shallow Epicontinental Sea. Springer Verlag, Berlin, pp. 11-32.

Reichenbacher B., Sienknecht U. 2001. Allopatric divergence and genetic diversity of recent Aphanius iberus and fossil Prolebias meyeri (Teleostei, Cyprinodontidae) from southwest and western Europe, as indicated by otoliths. Geobios 34: 69-83.

Reichenbacher B., Sienknecht U., Küchenhoff H., Fenske N. 2007. Combined otolith morphology and morphometry for assessing taxonomy and diversity in fossil and extant killifish (Aphanius, Prolebias). J. Morphol. 268: 898-915.

Reichenbacher B., Feulner G.R., Schulz-Mirbach T. 2009a. Geographic variation in otolith morphology among freshwater populations of Aphanius dispar (Teleostei, Cyprinodontiformes) from the Southeastern Arabian Peninsula. J. Morphol. 270: 469-484.

Reichenbacher B., Kamrani E., Esmaeili H.R., Teimori A. 2009b. The endangered cyprinodont Aphanius ginaonis (Holly, 1929) from southern Iran is a valid species: evidence from otolith morphology. Environ. Biol. Fish. 86: 507-521.

Rocco L., Ferrito V., Costagliola D., Marsilio A., Pappalardo A.M., Stingo V., Tigano C. 2007. Genetic divergence among and within four Italian populations of Aphanius fasciatus (Teleostei, Cyprinodontiformes). Ital. J. Zool. 74: 371-379.

Sarnthein M. 1972. Sediments and history of the postglacial transgression in the Persian Gulf and Northwest Gulf of Oman. Mar. Geol. 12: 245-266.

Smale M.J., Watson G., Hecht T. 1995. Otolith atlas of southern African marine fishes (Ichthyological Monographs). J.L.B. Smith Institute of Ichthyology, Grahamstown, $253 \mathrm{pp}$.

Smith D.E., Harrison S., Firth C.R., Jordan J.T. 2011. The early Holocene sea level rise. Quat. Sci. Rev. 30: 1846-1860.

SPSS Inc. 2011. SPSS. Ver. 19.0. Base. Chicago, IL: SPSS, Inc.

Schulz-Mirbach T., Reichenbacher B., Yildirim Z., Atalay A. 2006. Otolith characteristics of species, subspecies and populations of Aphanius Nardo, 1827 (Teleostei, Cyprinodontiformes) from Anatolia (Turkey). J. Nat. Hist. 40: 1687-1705.

Stransky C., Murta A.G., Schlickeisen J., Zimmermann C. 2008. Otolith shape analysis as a tool for stock separation of horse mackerel (Trachurus trachurus) in the Northeast Atlantic and Mediterranean. Fish. Res. 89: 159-166.

Teimori A., Schulz-Mirbach T., Esmaeili H.R., Reichenbacher B. 
2012a. Geographical differentiation of Aphanius dispar (Teleostei: Cyprinodontidae) from Southern Iran. Zool. Syst. Evol. Res. doi: 10.1111/j.1439-0469.2012.00667.x

Teimori A., Esmaeili H.R., Gholami Z., Zarei N., Reichenbacher B. 2012b. Aphanius arakensis, a new species of tooth-carp (Cyprinodontidae) from the endorheic Namak Lake Basin in Iran ZooKeys 215: 55-76.

Teller J.T., Glennie K.W., Lancaster N., Singhvi A.K. 2000. Calcareous dunes of the United Arab Emirates and Noah's flood: the postglacial reflooding of the Persian (Arabian) Gulf. Quat. Internat. 68-71: 297-308.

Tigano C., Canapa A., Ferrito V., Barucca M., Arcidiacono I., Deidon A., Schembri P.J., Olmo E. 2006. A study of osteological and molecular differences in populations of Aphanius fasciatus Nardo, 1827, from the central Mediterranean (Teleostei, Cyprinodontidae). Mar. Biol. 149: 1539-1550.

Torres G.J., Lombarte A., Morales-Nin B. 2000. Sagittal otolith size and shape variability to identify geographical intraspecific differences in three species of the genus Merluccius. J. Mar. Biol. Assoc. U.K. 80: 333-342.

Triantafyllidis A., Leonardos I., Bista I., Kyriazis I.D., Stoumboudi M.T.h., Kappas I., Amat F., Abatzopoulos T.J. 2007. Phylogeography and genetic structure of the Mediterranean killifish Aphanius fasciatus (Cyprinodontidae). Mar. Biol. 152: 1159-1167.
Tuset V.M., Azzurro E., Lombarte A. 2012. Identification of Lessepsian fish species using the sagittal otolith. Sci. Mar. doi: 10.3989/scimar.03420.18E

Tuset V.M., Lombarte A., Assis C. 2008. Otolith atlas for the western Mediterranean, north and central eastern Atlantic. Sci. Mar. 72S1: 7-198.

Vignon M., Morat F. 2010. Environmental and genetic determinant of otolith shape revealed by a nonindigenous tropical fish. Mar. Ecol. Prog. Ser. 411: 231-241.

Volpedo A.V., Echeverría D.D. 2000. Catálogo y claves de otolitos para la identificación de peces del mar Argentino. Editorial Dunken, Buenos Aires, 88 pp.

Wildekamp R.H. 1993. A world of killies. Atlas of the oviparous cyprinodontiform fishes of the world. The genera Adamas, Adinia, Aphanius, Aphyoplatys and Aphyosemion. Amer. Killifish. Ass. Indiana, $384 \mathrm{pp}$.

Zöllei L., Learned-Miller E., Grimson E., Wells W. 2005. Efficient population registration of $3 \mathrm{~d}$ data. In CVBIA'05 Proceedings of the First international conference on Computer Vision for Biomedical Image Applications. 3765: 291-301.

Guest ed.: A. Lombarte.

Scient. ed.: D. Vaqué

Received April 10, 2012. Accepted September 14. 2012.

Published online October 26, 2012. 